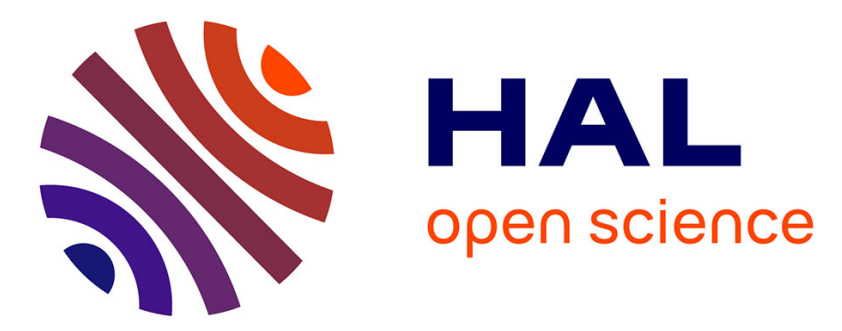

\title{
N-C Axially Chiral Compounds with an ortho -Fluoro Substituent and Steric Discrimination between Hydrogen and Fluorine Atoms Based on a Diastereoselective Model Reaction
}

Asumi Iida, Mizuki Matsuoka, Hiroshi Hasegawa, Nicolas Vanthuyne, Daniel Farran, Christian Roussel, Osamu Kitagawa

\section{To cite this version:}

Asumi Iida, Mizuki Matsuoka, Hiroshi Hasegawa, Nicolas Vanthuyne, Daniel Farran, et al.. N-C Axially Chiral Compounds with an ortho -Fluoro Substituent and Steric Discrimination between Hydrogen and Fluorine Atoms Based on a Diastereoselective Model Reaction. Journal of Organic Chemistry, 2019, 84 (6), pp.3169-3175. 10.1021/acs.joc.8b03043 . hal-02514527

\author{
HAL Id: hal-02514527 \\ https://hal.science/hal-02514527
}

Submitted on 23 Mar 2020

HAL is a multi-disciplinary open access archive for the deposit and dissemination of scientific research documents, whether they are published or not. The documents may come from teaching and research institutions in France or abroad, or from public or private research centers.
L'archive ouverte pluridisciplinaire HAL, est destinée au dépôt et à la diffusion de documents scientifiques de niveau recherche, publiés ou non, émanant des établissements d'enseignement et de recherche français ou étrangers, des laboratoires publics ou privés. 


\title{
$\mathrm{N}-\mathrm{C}$ Axially Chiral Compounds with an ortho-Fluoro Substituent and Steric Discrimination between Hydrogen and Fluorine Atoms Based on a Diastereoselective Model Reaction
}

\author{
Iida, A. \\ Matsuoka, M. \\ Hasegawa, $\mathrm{H}$. \\ Vanthuyne, N. \\ Farran, D. \\ Roussel, $C$. \\ Kitagawa, O.
}

\begin{abstract}
The fluorine atom is the second smallest atom; nevertheless, the ortho-fluoro group may lead to stable $N$-aryl atropisomers when the steric demand of the flanking substituents is large enough. 2-Alkyl-3-(2-fluorophenyl)quinazolin-4-ones and 3-(2fluorophenyl)-4-methylthiazoline-2-thione were found to be the first $\mathrm{N}$-aryl axially chiral compounds bearing an ortho-fluoro group whose enantiomers were isolated at ambient temperature. The reaction of alkyl halides with the anionic species prepared from 2-ethyl-3(2-fluorophenyl)quinazolin-4-one presenting an $\mathrm{N}-\mathrm{C}$ axial chirality provided a model

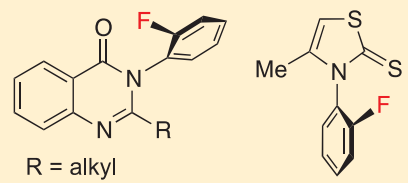

"axially chiral" $\left(\Delta \mathrm{G}^{\ddagger}=26.1-28.3 \mathrm{kcal} / \mathrm{mol}\right)$ reaction for quantitative evaluation of the steric discrimination (slight difference of steric factor) between hydrogen and fluorine atoms. In the case of low steric demand (allylation reaction) no diastereoselectivity was detected, while in the case of high steric demand (isopropylation reaction) the diastereoselectivity became significant.
\end{abstract}

\section{INTRODUCTION}

Recently, chiral molecules due to the rotational restriction around an $\mathrm{N}-\mathrm{Ar}$ bond have attracted considerable attention as a new class of nonbiaryl atropisomeric compound. ${ }^{1}$ Most of these chiral molecules have an ortho-substituted aniline skeleton, and the rotational stability around an $\mathrm{N}-\mathrm{Ar}$ axis is significantly influenced by the structure on the nitrogen side as well as the steric factor of an ortho substituent on the Ar group. For example, in anilide derivatives, a bulky ortho substituent such as a tert-butyl group is required for a rotationally stable structure, ${ }^{2}$ while among 3-arylthiazoline-2thiones (Figure 1, I) and 3-arylquinazolin-4-ones (Figure 1, II), compounds IB, IC, IIB, and IIC bearing relatively small ortho substituents such as $\mathrm{Cl}$ and $\mathrm{Me}$ groups possess a stable atropisomeric structure. ${ }^{3,4}$

On the other hand, the $\mathrm{N}-\mathrm{C}$ axially chiral compounds bearing an ortho-fluoro group have to date remained uncommon because the steric size of a fluorine atom is supposedly too small to restrict the rotation around the $\mathrm{N}-\mathrm{Ar}$ bond. Indeed, in 3-arylthiazoline-2-thione $\mathrm{I}$, the rotational barrier of IA $(\mathrm{X}=\mathrm{F})$ is significantly lower $(12.2 \mathrm{kcal} / \mathrm{mol})$ than that of IB $(\mathrm{X}=\mathrm{Cl}) .{ }^{3 \mathrm{C}}$ Also, among 3-arylquinazolin-4-one derivatives, it has been reported that the compound shown in Figure 1, IIIA (a smooth muscle contractile agent), with its ortho-fluorophenyl group is rotationally unstable, and its enantiomers could not be isolated at ambient temperature. ${ }^{5}$ Furthermore, although the antiviral quinazolinone shown in Figure 1, IVA, is also well known, there is no report of its N-C axial chirality. ${ }^{6}$ To the best of our knowledge, the known ortho-

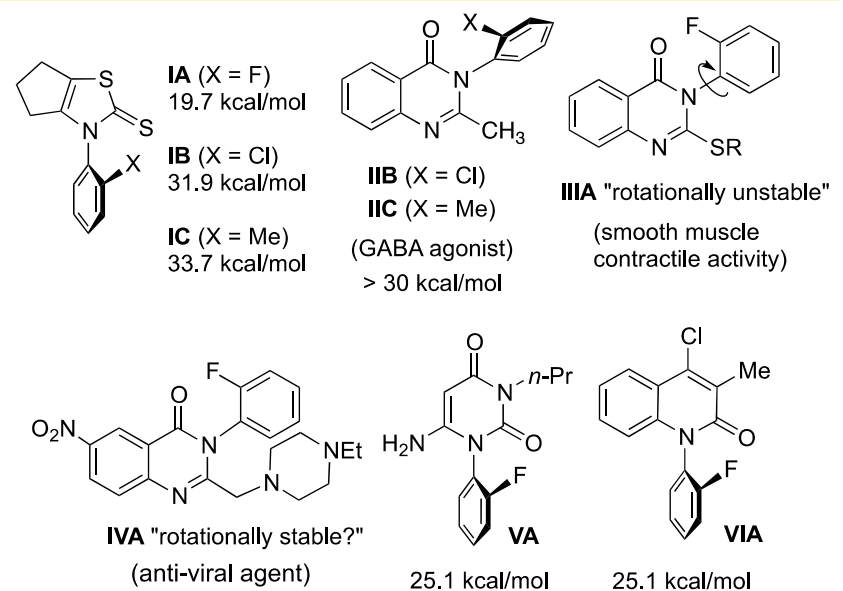

Figure 1. Various $\mathrm{N}-\mathrm{C}$ axially chiral compounds and their rotational barriers.

fluoro-aniline derivatives with the highest rotational barrier are pyrimidine-2,4-dione VA and quinolin-2-one VIA (Figure 1). The rotational barriers of VA and VIA are $25.1 \mathrm{kcal} / \mathrm{mol}$; such barriers are high enough to allow a baseline separation without interconversion of the enantiomers on the column; however, collection and storage of the enantiomers require special care to prevent racemization $\left(t_{1 / 2}=1.4\right.$ days at $\left.298 \mathrm{~K}\right){ }^{7,8}$ 
As shown in eq 1 , we recently reported the $\alpha$-alkylation of anionic species prepared from $\mathrm{N}-\mathrm{C}$ axially chiral 2-ethyl-

$$
\begin{aligned}
& \text { 1) } \mathrm{LiHMDS} \\
& \mathbf{2 a}\left(\mathrm{F}, \mathrm{Cl}, \mathrm{Me}, \mathrm{Br}, \mathrm{Et}, \mathrm{I}, i-\mathrm{Pr}, \mathrm{CF}_{3} \quad \mathrm{R}=\mathrm{Et} \text {, allyl, methallyl, benzyl, } i-\mathrm{Pr}\right. \\
& \mathrm{THF}, \mathrm{R} \text { (axially chiral) }
\end{aligned}
$$

quinazolin-4-ones bearing various ortho-substituted phenyl groups on the nitrogen atom. ${ }^{9}$ The reaction proceeded with stereocontrol due to axial chirality to preferentially afford the products 2 with a $(P, S)$-configuration.

In the course of this work, it was found that no $\mathrm{N}-\mathrm{C}$ bond rotation occurs in the diastereomeric allylation product $2 \mathrm{a}(\mathrm{X}$ $=\mathrm{F}, \mathrm{R}=$ allyl) bearing an ortho-fluorophenyl group even after standing for $24 \mathrm{~h}$ at $\mathrm{rt}$ in THF (eq 1). ${ }^{9 \mathrm{~b}}$ The unexpected rotational stability of $\mathbf{2 a}$ aroused our interest for the atropisomerism resulting from fluorine as a blocking substituent and for experimental evidence of the steric discrimination between the two smallest substituents: fluorine and hydrogen. In this article, we discuss several rare $\mathrm{N}-\mathrm{C}$ axially chiral compounds (3-arylquinazolin-4-ones and 3arylthiazoline-2-thiones) bearing a $\mathrm{N}$-ortho-fluorophenyl group. We also describe the reaction of alkyl halides with the anionic species prepared from 2-ethyl-3-(2-fluorophenyl)quinazolin-4-one with stereocontrol based on the discrimination between ortho-hydrogen and ortho-fluorine atoms.

\section{RESULTS AND DISCUSSION}

Initially we thought that the rotational stability of $\mathbf{2 a}$, which differs from that of IIIA, may be due to the bulky alkyl group at $\mathrm{C} 2$. To verify the substituent effect at C2, 3-(2-fluorophenyl)quinazolin-4-ones $1 \mathrm{a}-\mathrm{c}$ bearing three $\mathrm{C} 2$-alkyl groups $(\mathrm{Me}, \mathrm{Et}$, $i$-Pr) were prepared by cyclocondensation of the corresponding $N$-acylanthranilic acid with 2-fluoroaniline, followed by HPLC enantiomer separation using a Chiralpak AS-H column. Subsequently, the rate constants for the racemization of the obtained optically pure $1 \mathrm{a}-\mathbf{c}$ were measured at three different temperatures in $\mathrm{CCl}_{4}$, and these data were subjected to an Eyring plot to determine the rotational barriers (Figure 2 and see SI).

$\begin{array}{llcc}1 \mathbf{1 a}(\mathrm{R}=\mathrm{Et}) & 26.5 & 17.0 \\ \mathbf{1 b}(\mathrm{R}=\mathrm{Me}) & 26.1 & 8.7 \\ \mathbf{1 c}(\mathrm{R}=i-\mathrm{Pr}) & 26.2 & 10.4\end{array}$

Figure 2. Rotational barriers and half-life time of quinazolinones 1ac at $25{ }^{\circ} \mathrm{C}$ in $\mathrm{CCl}_{4}$.

The rotational barrier and half-life time for the racemization

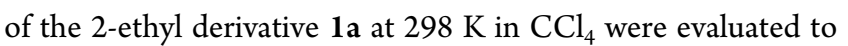
be $26.5 \mathrm{kcal} / \mathrm{mol}$ and 17 days, demonstrating sufficient stability for a convenient isolation of the enantiomers. For the 2-methyl and 2-isopropyl derivatives $\mathbf{1 b}$ and $\mathbf{1 c}$, although a slight decrease in the rotational barriers was observed (26.1 and 26.2 $\mathrm{kcal} / \mathrm{mol}$ ), rotational stability at ambient temperature was maintained $\left(t_{1 / 2}\right.$ of $\mathbf{1 b}$ and $\mathbf{1} \mathbf{c}$ at $25{ }^{\circ} \mathrm{C}=8.7$ and 10.4 days $)$. These results indicate that the rotational barriers in quinazolinone derivatives bearing an ortho-fluorophenyl group are not remarkably affected by the steric effect of the $\mathrm{C} 2$-alkyl group in the series $\mathrm{Me}, \mathrm{Et}, \mathrm{i}$-Pr.

The rotational instability of IIIA, which markedly differs from the high rotational stability in $1 \mathbf{a}-\mathbf{c}$, may be explained with reference to Figure 3. We previously reported that the N-

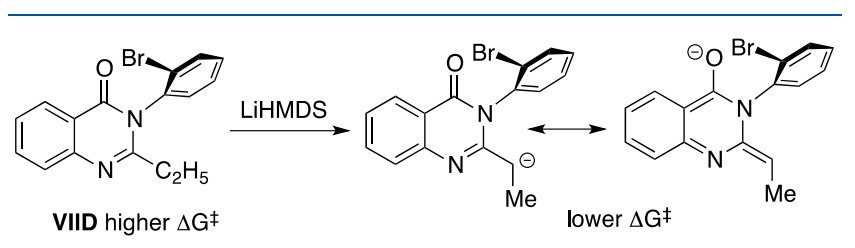<smiles>CCc1nc2ccccc2c(=O)n1-c1ccccc1F</smiles>

1a higher $\Delta \mathrm{G}^{\ddagger}$

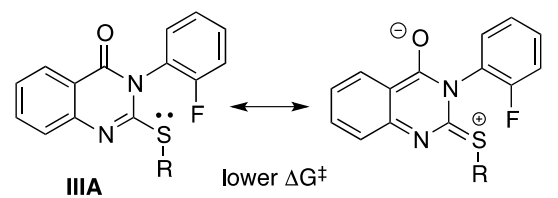

Figure 3. Relationship between nearby structures and the rotational barrier around an $\mathrm{N}-\mathrm{C}$ bond.

C bond rotation of the anionic species prepared from quinazolinone VIID with an ortho-bromophenyl group occurs easily at ambient temperature, in remarkable contrast with neutral VIID, which presents a high rotational barrier (ca. $\Delta G^{\ddagger}$ $=35 \mathrm{kcal} / \mathrm{mol}) .^{9 \mathrm{a}}$ The structure of quinazolinone IIIA with an alkylthio group at $\mathrm{C} 2$ may be similar to the anionic species of VIID because of the positive resonance effect involving the lone electron pair on sulfur. The electron-donating effect of the sulfur atom in IIIA would be weak in comparison with that in the anionic intermediate VIID. Meanwhile, since the rotational barriers of quinazolinones bearing an ortho-fluorophenyl group are not so high (ca. $\Delta G^{\ddagger}=26 \mathrm{kcal} / \mathrm{mol}$ ), the slight decrease in the barrier caused by the weak electron-donating character of sulfur atom may result in the difficulty of the enantiomer separation in VIID. In addition, a possible attractive electrostatic interaction between the electron-rich fluorine atom and the positively charged sulfur atom in the near planar transition state of the $\mathrm{N}-\mathrm{C}$ bond rotation may account for the relative rotational instability in IIIA.

Although the rotationally stable quinazolinone derivatives 1a-c bearing an ortho-fluorophenyl group were found unexpectedly, ${ }^{10}$ we designed other $\mathrm{N}-\mathrm{C}$ axially chiral compounds $[N$-(ortho-fluorophenyl)thiazoline-2-thione derivatives 3] to have a higher rotational barrier than 1a-c. As mentioned above, cyclopentane-fused thiazoline-2-thione IA is rotationally unstable at ambient temperature $\left(\Delta G^{\ddagger}=19.7\right.$ $\mathrm{kcal} / \mathrm{mol}$, Figures 1 and 4$){ }^{3 \mathrm{c}}$ In order to increase the rotational barrier by structural modification, we envisioned the

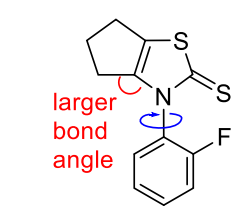

IA

$\Delta \mathrm{G}^{\ddagger} 19.7 \mathrm{kcal} / \mathrm{mo}$ at $5^{\circ} \mathrm{C}$ in hexane : $\mathrm{EtOH}=7: 3$

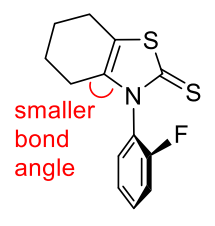

$3 a$

$27.9 \mathrm{kcal} / \mathrm{mol}$ at $78^{\circ} \mathrm{C}$ in $\mathrm{EtOH}$

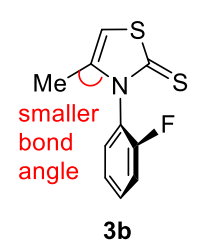

$28.3 \mathrm{kcal} / \mathrm{mol}$ at $78^{\circ} \mathrm{C}$ in $\mathrm{EtOH}$
Figure 4. Rotational barriers in $\mathrm{N}$-(2-fluorophenyl)thiazoline-2-thione derivatives. 
introduction of different groups on position 4 of the heterocyclic moiety. Indeed, previously described X-ray crystal analyses of $\mathrm{N}$-aryl-thiazoline-2-thiones showed unambiguously that the resulting rotational barriers in these series were directly related to the angle between the endocyclic nitrogen atom and the substituent on position 4 of the thiazoline ring. ${ }^{11}$ For instance, this angle, which is crucial for enantiomeric stability, was found to be $120-121^{\circ}$ for 4-methyl thiazoline-2thiones, ${ }^{11}$ compared to the $131^{\circ}$ found for the five-membered ring analogues, ${ }^{3 \mathrm{C}}$ making the rotation about the pivotal bond more difficult in the first case. Thus, the targeted cyclohexanefused and 4-methylated $\mathrm{N}$-(ortho-fluorophenyl)-thiazoline-2thiones $\mathbf{3} \mathbf{a}$ and $\mathbf{3} \mathbf{b}$ (Figure 4) were synthesized by treatment of ortho-fluoroaniline with carbon disulfide to generate the dithiocarbamate salt, which was allowed to react with 2chlorocyclohexanone or 2-chloroacetone, respectively (see SI). ${ }^{11}$

Enantiomers were easily obtained by preparative HPLC on the chiral support of an $(S, S)$ Whelk-O1 column, and kinetic studies of the thermal racemization of the atropisomers permitted measurement of the rotational barriers at a specified temperature. As expected, these structural modifications notably increased the rotational barriers. For compound 3a, a $\Delta G^{\ddagger}$ value of $27.9 \mathrm{kcal} / \mathrm{mol}$ in ethanol at $78{ }^{\circ} \mathrm{C}$ was obtained, i.e., much larger than that of IA. In the same conditions, the barrier to rotation for $3 \mathbf{b}$ was measured at $28.3 \mathrm{kcal} / \mathrm{mol}$, corresponding to a half-life for racemization of 823 days at 20 ${ }^{\circ} \mathrm{C}$. These two very close results revealed that substituents in position 4 on the thiazoline ring of $3 a$ and $3 \mathbf{b}$ produced a similar spatial requirement. Thus, despite the size of the fluorine atom, we demonstrated that a judiciously substituted $\mathrm{N}$-(ortho-fluorophenyl) atropisomer could have a high enough rotational barrier to be isolated and handled without risk of racemization. These barriers are strictly originating from the steric size of the fluorine atom, and they do not involve a possible electrostatic repulsive interaction between the electron-rich fluorine atom and the flanking sulfur atom of the thiazoline-2-thione. This conclusion is firmly derived from the $\mathrm{Cl} / \mathrm{Me}$ barrier ranking which was first disclosed by Colebrook et al. in $1973,{ }^{12}$ that is, when the barrier to rotation of an aryl ring bearing an ortho- $\mathrm{Cl}$ is larger than the barrier of the ortho-Me analogue, the origin of that barrier order results from an electrostatic repulsive interaction between the chlorine and a negatively charged flanking substituent. On the other hand, when the pure steric difference between a chlorine and a methyl group is operating, the barrier is larger for the methyl derivative. In thiazoline-2-thiones IB and IC, the barrier is larger for the ortho-methyl derivative IC; the same holds true for the 4-Me derivative. ${ }^{13}$ Thus, the barriers of $\mathbf{3 a}$ and $\mathbf{3 b}$ are resulting from pure steric repulsion.

Table 1 outlines a proper stereoselective reaction, which discriminates on the basis of the slight difference in the steric size between hydrogen and fluorine atoms. ${ }^{14}$ We have already shown that the stereocontrolled allylation of the anionic species derived from 2-ethylquinazolin-4-one 1 (eq 1) strongly depended on the steric influence of ortho substituents $(X)$, that is, the diastereoselectivity decreased with decreasing bulkiness of $\mathrm{X}$ and completely vanished in allylation of the ortho-fluoro derivative 1a (X $=\mathrm{F}$, Table 1 , entry 1$)$. Since the magnitude of the diastereoselectivity might be influenced by the bulkiness of the alkyl halide as well as by the ortho substituent, ${ }^{9 a}$ the reaction of the ortho-fluorophenyl compound 1a with other alkyl halides was further examined (Table 1).
Table 1. $\alpha$-Alkylation with Quinazolinone 1a Bearing an ortho-Fluorophenyl Group
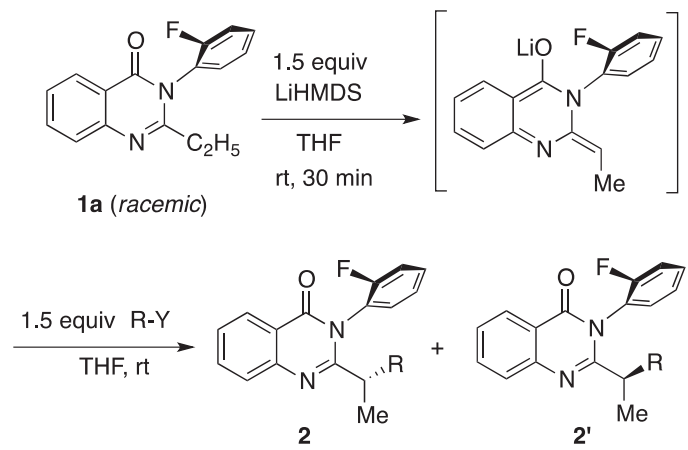

\begin{tabular}{clcccc} 
entry & \multicolumn{1}{c}{$\mathrm{R}-\mathrm{Y}$} & time $(\mathrm{h})$ & $\mathbf{2}, \mathbf{2}^{\prime}$ & yield $(\%)^{a}$ & $\mathrm{dr} 2 / 2^{\prime}$ \\
1 & allyl-Br & 0.5 & $\mathbf{2 a}, \mathbf{2 \mathbf { a } ^ { \prime }}$ & 96 & $1.0^{b}$ \\
2 & methallyl-Br & 0.5 & $\mathbf{2 b}, \mathbf{2 \mathbf { b } ^ { \prime }}$ & 86 & $2.0^{b}$ \\
3 & benzyl-Br & 0.5 & $\mathbf{2 c}, \mathbf{2 \mathbf { c } ^ { \prime }}$ & 82 & $2.0^{c}$ \\
4 & i-Pr-I & 24 & $\mathbf{2 d}, \mathbf{2 d ^ { \prime }}$ & 84 & $5.4^{b}$ \\
5 & cyc-C $_{6} \mathrm{H}_{11}-\mathrm{I}$ & 24 & $\mathbf{2 e}, \mathbf{2 \mathbf { e } ^ { \prime }}$ & 53 & $4.9^{b}$
\end{tabular}

${ }^{a}$ Isolated yield. ${ }^{b}$ Ratio based on the isolated yield. ${ }^{c}$ Ratio based on ${ }^{1} \mathrm{H}$ NMR analysis of the mixture of $\mathbf{2}$ and $\mathbf{2}$ '.

The reaction of methallyl and benzyl bromides with the anionic species prepared from 1a (racemate) and LiHMDS at rt in THF was completed within 30 min to give the products $\mathbf{2 b}, \mathbf{2} \mathbf{b}^{\prime}$ and $\mathbf{2 c}, \mathbf{2} \mathbf{c}^{\prime}$ in good yields ( $86 \%$ and $82 \%$, entries 2 and $3)$. In these alkylations, slight diastereoselectivity was observed $(\mathrm{dr}=2.0)$. Although the reaction with bulky isopropyl iodide required a longer reaction time $(24 \mathrm{~h}$ at $\mathrm{rt})$, the products $2 \mathrm{~d}$ and $\mathbf{2} \mathbf{d}^{\prime}$ were obtained with good yield $(84 \%)$ and moderate diastereoselectivity $\left(\mathbf{2 d} / \mathbf{2} \mathrm{d}^{\prime}=5.4\right.$, entry 4$)$. The reaction with cyclohexyl iodide also gave products $2 \mathbf{e}$ and $2 \mathbf{e}^{\prime}$ with moderate diastereoselectivity $\left(\mathbf{2} \mathbf{e} / \mathbf{2} \mathbf{e}^{\prime}=4.9\right)$ with a lower chemical yield (53\%) due to competition with the elimination reaction (entry 5).

All of the diastereomeric products $\mathbf{2 a}-\mathbf{e}$ and $\mathbf{2} \mathbf{a}^{\prime}-\mathbf{e}^{\prime}$ shown in Table 1 were completely separated by MPLC and isolated without any isomerization at rt. Furthermore, when diastereomerically pure alkylation products $\mathbf{2 a}$ and $\mathbf{2 d}$ were left to stand for 1 and $24 \mathrm{~h}$, respectively, under $\alpha$-alkylation conditions (in the presence of LiHMDS in THF), no isomerization to another diastereomer was observed. ${ }^{15}$ Thus, it is clear that the diastereomer ratios listed in Table 1 were determined by kinetic control.

One may argue that the observed diastereoselectivity is composed of steric and electrostatic contributions of the fluorine atom. The electrostatic contribution can be easily ruled out since we previously revealed that the diastereoselectivities during the allylation reaction with axially chiral quinazolinones bearing halogen $(\mathrm{F}, \mathrm{Cl}, \mathrm{Br}, \mathrm{I})$ and methyl groups at the ortho position were closely correlated with the van der Waals radii of the ortho substituents. ${ }^{9 b}$ The occurrence of electrostatic contribution for the halogens would have driven out the methyl group from the correlation. During the alkylation reactions reported in Table 1 the same electronic pattern is operating for all of the alkylation TS, and thus, the conclusion derived from the allylation holds for larger alkylating agents. In conclusion, the origin of the observed diastereoselectivities is mainly steric. ${ }^{16}$

The relative configuration of the major diastereomer 2 was determined to be $\left(P^{*}, S^{*}\right)$ on the basis of the X-ray crystal 
structural analysis of $\mathbf{2 d}$ (Figure 5). ${ }^{17}$ The diastereoselectivity can be explained as being due to the fact that the anionic

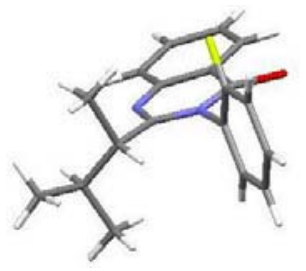

X-Ray crystal structure of $\mathbf{2 d}$

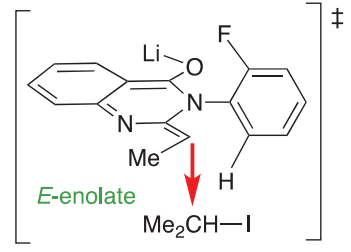

TS-2D
Figure 5. Stereochemical assignment of $\mathbf{2 d}$ and the origin of the diastereoselectivity.

species with E-geometry is selectively formed by treatment of 1a with LiHMDS, and the subsequent attack of a bulky alkyl halide preferentially occurs on the opposite site of the orthofluoro group (Figure 5, TS-2D).

\section{CONCLUSION}

We found rare stable $\mathrm{N}-\mathrm{C}$ axially chiral compounds (2-alkyl3-arylquinazolin-4-one and 3-arylthiazoline-2-thione derivatives) bearing an ortho-fluorophenyl group. These have sufficient rotational stability for the enantiomer separation. A proper stereoselective $\alpha$-alkylation, which discriminates on the basis of the slight steric size difference of hydrogen and fluorine atoms around $\mathrm{N}-\mathrm{C}$ chiral axis, was also achieved. In addition, as shown in Figure $1,{ }^{4-6} 3$-aryl-2-substituted quinazolinone derivatives are pharmaceutically attractive compounds, and our results indicate that in any drug development with quinazolin-4-one derivatives bearing an ortho-substituted phenyl group at the $\mathrm{N} 3$ position, the $\mathrm{N}-\mathrm{C}$ axial chirality should always be considered. ${ }^{18}$

The occurrence of stable atropisomers in $\mathrm{N}$-o-fluorophenyl derivatives and the diastereoselectivity results in the model reaction are conceptually linked, they demonstrate that the "steric" contribution of the fluorine atom becomes noticeable under strong steric demand of the nearby framework. Our findings add to the discussion on the bioisostericity of fluorine and hydrogen in drug design: ${ }^{19}$ in terms of steric contribution, the replacement of a hydrogen by a fluorine will not be significant in the case of weak steric demand in the receptor pocket, on the contrary a noticeable steric effect is expected in the case of strong steric demand.

\section{EXPERIMENTAL SECTION}

Melting points were uncorrected. ${ }^{1} \mathrm{H}$ and ${ }^{13} \mathrm{C}$ NMR spectra were recorded on a $400 \mathrm{MHz}$ spectrometer. In ${ }^{1} \mathrm{H}$ and ${ }^{13} \mathrm{C}$ NMR spectra, chemical shifts were expressed in $\delta(\mathrm{ppm})$ downfield from $\mathrm{CHCl}_{3}$ $(7.26 \mathrm{ppm})$ and $\mathrm{CDCl}_{3}(77.0 \mathrm{ppm})$, respectively. HRMS were recorded on a double-focusing magnetic sector mass spectrometer using electron impact ionization. Column chromatography was performed on silica gel $(75-150 \mu \mathrm{m})$. Medium-pressure liquid chromatography (MPLC) was performed on a $25 \times 4 \mathrm{~cm}$ i.d. prepacked column (silica gel, $10 \mu \mathrm{m}$ ) with a UV detector. Highperformance liquid chromatography (HPLC) was performed on a 25 $\times 0.4 \mathrm{~cm}$ i.d. chiral column with a UV detector.

3-(2-Fluorophenyl)-2-ethylquinazolin-4(3H)-one (1a). Under $\mathrm{N}_{2}$ atmosphere, to 2-fluoroaniline $(278 \mathrm{mg}, 2.5 \mathrm{mmol})$ and $\mathrm{N}$ propionyl anthranilic acid $(386 \mathrm{mg}, 2.0 \mathrm{mmol})$ in toluene $(6.0 \mathrm{~mL})$ was added $\mathrm{PCl}_{3}(412 \mathrm{mg}, 3.0 \mathrm{mmol})$, and the reaction mixture was stirred for $30 \mathrm{~min}$ at $\mathrm{rt}$ and for $7 \mathrm{~h}$ at $130{ }^{\circ} \mathrm{C}$. The mixture was poured into water and extracted with AcOEt. The AcOEt extracts were washed with brine, dried over $\mathrm{MgSO}_{4}$, and evaporated to dryness.
Purification of the residue by column chromatography (hexane/ AcOEt $=4)$ gave 1a $(499 \mathrm{mg}, 93 \%)$. 1a(racemate): white solid; mp $85-86{ }^{\circ} \mathrm{C}$; IR (neat) $1697 \mathrm{~cm}^{-1}$; ${ }^{1} \mathrm{H} \mathrm{NMR}\left(400 \mathrm{MHz}, \mathrm{CDCl}_{3}\right) \delta 8.28$ $(1 \mathrm{H}, \mathrm{dd}, J=1.6,8.0 \mathrm{~Hz}), 7.72-7.80(2 \mathrm{H}, \mathrm{m}), 7.45-7.54(2 \mathrm{H}, \mathrm{m})$, $7.28-7.35(3 \mathrm{H}, \mathrm{m}), 2.47(2 \mathrm{H}, \mathrm{q}, J=7.2 \mathrm{~Hz}), 1.24(3 \mathrm{H}, \mathrm{t}, J=7.2 \mathrm{~Hz})$; ${ }^{13} \mathrm{C}\left\{{ }^{1} \mathrm{H}\right\}$ NMR $\left(100 \mathrm{MHz}, \mathrm{CDCl}_{3}\right) \delta 161.8,157.7\left(\mathrm{~d}, J_{\mathrm{C}-\mathrm{F}}=249.8\right.$ $\mathrm{Hz}), 157.3,147.4,134.6,131.3\left(\mathrm{~d}, J_{\mathrm{C}-\mathrm{F}}=7.6 \mathrm{~Hz}\right), 130.1,127.1,127.0$, $126.6,125.1\left(\mathrm{~d}, J_{\mathrm{C}-\mathrm{F}}=3.8 \mathrm{~Hz}\right), 124.8\left(\mathrm{~d}, J_{\mathrm{C}-\mathrm{F}}=14.3 \mathrm{~Hz}\right) 120.4$, $116.9\left(\mathrm{~d}, J_{\mathrm{C}-\mathrm{F}}=19.0 \mathrm{~Hz}\right), 28.7,10.8$; $\mathrm{MS}(\mathrm{m} / z) 291\left(\mathrm{MNa}^{+}\right)$; HRMS calcd for $\mathrm{C}_{16} \mathrm{H}_{13} \mathrm{FN}_{2} \mathrm{NaO}\left(\mathrm{MNa}^{+}\right)$291.0910, found 291.0888. The enantiomers of 1 a were separated by HPLC using a Chiralpak AS-H column $[25 \mathrm{~cm} \times 0.46 \mathrm{~cm}$ i.d.; $15 \% i-\mathrm{PrOH}$ in hexane; flow rate 0.8 $\mathrm{mL} / \mathrm{min}, 1 \mathrm{a} ; t_{\mathrm{R}}=6.9 \mathrm{~min}$, ent-1a; $\left.t_{\mathrm{R}}=9.4 \mathrm{~min}\right]$.

3-(2-Fluorophenyl)-2-methylquinazolin-4(3H)-one (1b). 1b was prepared from 2-fluoroaniline $(319 \mathrm{mg}, 2.5 \mathrm{mmol})$ and $\mathrm{N}$-acetyl anthranilic acid $(358 \mathrm{mg}, 2.0 \mathrm{mmol})$ in accordance with the procedure for the synthesis of 1a. Purification of the residue by column chromatography (hexane/AcOEt $=2)$ gave $\mathbf{1 b}(458 \mathrm{mg}, 90 \%) . \mathbf{1 b}$ : white solid; mp $100-102{ }^{\circ} \mathrm{C}$; IR (neat) $1680 \mathrm{~cm}^{-1}$; ${ }^{1} \mathrm{H}$ NMR (400 $\left.\mathrm{MHz}, \mathrm{CDCl}_{3}\right) \delta 8.26(1 \mathrm{H}, \mathrm{dd}, J=1.2,8.0 \mathrm{~Hz}), 7.76(1 \mathrm{H}, \mathrm{dt}, J=1.6$, $8.0 \mathrm{~Hz}), 7.67(1 \mathrm{H}, \mathrm{d}, J=7.6 \mathrm{~Hz}), 7.44-7.53(2 \mathrm{H}, \mathrm{m}), 7.26-7.32$ $(3 \mathrm{H}, \mathrm{m}), 2.27(3 \mathrm{H}, \mathrm{s}) ;{ }^{13} \mathrm{C}\left\{{ }^{1} \mathrm{H}\right\}$ NMR $\left(100 \mathrm{MHz}, \mathrm{CDCl}_{3}\right) \delta 161.7$, $157.7\left(\mathrm{~d}, J_{\mathrm{C}-\mathrm{F}}=249.8 \mathrm{~Hz}\right), 153.9,147.5,134.9,131.5\left(\mathrm{~d}, J_{\mathrm{C}-\mathrm{F}}=7.6\right.$ $\mathrm{Hz}), 130.0,127.2,126.94,126.87,125.4\left(\mathrm{~d}, J_{\mathrm{C}-\mathrm{F}}=4.8 \mathrm{~Hz}\right), 125.3(\mathrm{~d}$, $\left.J_{\mathrm{C}-\mathrm{F}}=15.2 \mathrm{~Hz}\right), 120.5,117.1\left(\mathrm{~d}, J_{\mathrm{C}-\mathrm{F}}=20.0 \mathrm{~Hz}\right), 23.7$; MS $(\mathrm{m} / z)$ $277\left(\mathrm{MNa}^{+}\right)$; HRMS calcd for $\mathrm{C}_{15} \mathrm{H}_{11} \mathrm{FN}_{2} \mathrm{NaO}\left(\mathrm{MNa}^{+}\right)$277.0753, found 277.0753. The enantiomers of $\mathbf{1 b}$ were separated by HPLC using chiral AS-H column $[25 \mathrm{~cm} \times 0.46 \mathrm{~cm}$ i.d.; $15 \% i$-PrOH in hexane; flow rate $0.8 \mathrm{~mL} / \mathrm{min}, 1 \mathbf{b} ; t_{\mathrm{R}}=8.5 \mathrm{~min}$, ent-1 $\mathbf{b} ; t_{\mathrm{R}}=11.7$ $\min ]$.

3-(2-Fluorophenyl)-2-isopropylquinazolin-4(3H)-one (1c). Under $\mathrm{N}_{2}$ atmosphere, to the solution of rac-1a $(80 \mathrm{mg}, 0.3 \mathrm{mmol})$ in THF $(2.0 \mathrm{~mL})$ was added THF solution of $\mathrm{LiN}\left(\mathrm{SiMe}_{3}\right)_{2}(1.3 \mathrm{M}$, $0.346 \mathrm{~mL}, 0.45 \mathrm{mmol}$ ) at $\mathrm{rt}$, and the mixture was stirred for $30 \mathrm{~min}$ at rt. Iodomethane $(64 \mathrm{mg}, 0.45 \mathrm{mmol})$ was added to the mixture at $\mathrm{rt}$. After being stirred for $30 \mathrm{~min}$ at $\mathrm{rt}$, the mixture was poured into $\mathrm{NH}_{4} \mathrm{Cl}$ aq and extracted with AcOEt. The AcOEt extracts were washed with brine, dried over $\mathrm{MgSO}_{4}$, and evaporated to dryness. Purification of the residue by column chromatography (hexane/ AcOEt $=4)$ gave $1 \mathrm{c}(74 \mathrm{mg}, 87 \%) .1 \mathrm{c}$ : white solid; $\mathrm{mp} 110-112{ }^{\circ} \mathrm{C}$; IR (neat) $1684 \mathrm{~cm}^{-1} ;{ }^{1} \mathrm{H}$ NMR $\left(400 \mathrm{MHz}, \mathrm{CDCl}_{3}\right) \delta 8.27(1 \mathrm{H}, \mathrm{dd}, J$ $=0.8,8.4 \mathrm{~Hz}), 7.72-7.79(2 \mathrm{H}, \mathrm{m}), 7.43-7.54(2 \mathrm{H}, \mathrm{m}), 7.28-7.35$ $(3 \mathrm{H}, \mathrm{m}), 2.68(1 \mathrm{H}, \mathrm{m}), 1.24(3 \mathrm{H}, \mathrm{d}, J=6.4 \mathrm{~Hz}), 1.23(3 \mathrm{H}, \mathrm{d}, J=6.4$ $\mathrm{Hz}) ;{ }^{13} \mathrm{C}\left\{{ }^{1} \mathrm{H}\right\}$ NMR $\left(100 \mathrm{MHz}, \mathrm{CDCl}_{3}\right) \delta 162.0,161.1,157.8(\mathrm{~d}$, $\left.J_{\mathrm{C}-\mathrm{F}}=249.8 \mathrm{~Hz}\right), 147.6,134.5,131.2\left(\mathrm{~d}, J_{\mathrm{C}-\mathrm{F}}=7.6 \mathrm{~Hz}\right), 130.2,127.1$, $126.9,126.5,125.0\left(\mathrm{~d}, J_{\mathrm{C}-\mathrm{F}}=3.8 \mathrm{~Hz}\right), 124.9\left(\mathrm{~d}, J_{\mathrm{C}-\mathrm{F}}=13.3 \mathrm{~Hz}\right)$, $120.4,116.9\left(\mathrm{~d}, J_{\mathrm{C}-\mathrm{F}}=20.0 \mathrm{~Hz}\right), 32.4,21.2,20.9$; $\mathrm{MS}(\mathrm{m} / z) 305$ $\left(\mathrm{MNa}^{+}\right)$; HRMS calcd for $\mathrm{C}_{17} \mathrm{H}_{15} \mathrm{FN}_{2} \mathrm{NaO}\left(\mathrm{MNa}^{+}\right)$305.1066, found 305.1062. The enantiomers of $1 \mathrm{c}$ were separated by HPLC using a Chiralpak AS-H column $[25 \mathrm{~cm} \times 0.46 \mathrm{~cm}$ i.d.; $15 \% i$-PrOH in hexane; flow rate $0.8 \mathrm{~mL} / \mathrm{min}, 1 \mathrm{c} ; t_{\mathrm{R}}=6.2 \mathrm{~min}$, ent $\left.-1 \mathrm{c} ; t_{\mathrm{R}}=8.1 \mathrm{~min}\right]$.

$\left(P *, S^{*}\right)$ - and $\left(P^{*}, R^{*}\right)-3$-(2-Fluorophenyl)-2-(pent-4-en-2-yl)quinazolin-4(3H)-one ( $2 \mathrm{a}$ and $\left.2 \mathrm{a}^{\prime}\right)$. Under $\mathrm{N}_{2}$ atmosphere, to the solution of rac-1a $(80 \mathrm{mg}, 0.3 \mathrm{mmol})$ in THF $(3.0 \mathrm{~mL})$ was added a THF solution of $\mathrm{LiN}\left(\mathrm{SiMe}_{3}\right)_{2}(1.3 \mathrm{M}, 0.346 \mathrm{~mL}, 0.45 \mathrm{mmol})$ at $\mathrm{rt}$, and the mixture was stirred for $30 \mathrm{~min}$ at $\mathrm{rt}$. Allyl bromide $(54 \mathrm{mg}$, $0.45 \mathrm{mmol}$ ) was added to the mixture at rt. After being stirred for 30 min at rt, the mixture was poured into $\mathrm{NH}_{4} \mathrm{Cl}$ aq and extracted with AcOEt. The AcOEt extracts were washed with brine, dried over $\mathrm{MgSO}_{4}$, and evaporated to dryness. Purification of the residue by column chromatography (hexane/AcOEt $=4$ ) gave mixtures of $\mathbf{2 a}$ and $2 \mathrm{a}^{\prime}$ (85 $\left.\mathrm{mg}, 96 \%\right)$. The diastereomer ratio of $\mathbf{2 a}$ and $2 \mathrm{a}^{\prime}(1: 1)$ was determined on the basis of isolated yield. $\mathbf{2 a}$ and $\mathbf{2} \mathbf{a}^{\prime}$ were completely separated by medium-pressure liquid chromatography (MPLC, eluent hexane/AcOEt $=8$ ) to give diastereomerically pure $\mathbf{2 a}$ and $2 \mathrm{a}^{\prime}$ (40 mg, $43 \%$ and $41 \mathrm{mg}, 44 \%$ ). 2a: white solid; mp 77-80 ${ }^{\circ} \mathrm{C}$; IR (neat) $1692 \mathrm{~cm}^{-1}$; ${ }^{1} \mathrm{H}$ NMR $\left(400 \mathrm{MHz}, \mathrm{CDCl}_{3}\right) \delta 8.27(1 \mathrm{H}$, $\mathrm{dd}, J=1.2,7.6 \mathrm{~Hz}), 7.73-7.80(2 \mathrm{H}, \mathrm{m}), 7.44-7.54(2 \mathrm{H}, \mathrm{m}), 7.24-$ $7.35(3 \mathrm{H}, \mathrm{m}), 5.62(1 \mathrm{H}, \mathrm{m}), 4.98(1 \mathrm{H}, \mathrm{dd}, J=1.2,16.8 \mathrm{~Hz}), 4.94$ $(1 \mathrm{H}, \mathrm{dd}, J=2.0,10.0 \mathrm{~Hz}), 2.57-2.68(2 \mathrm{H}, \mathrm{m}), 2.23(1 \mathrm{H}, \mathrm{m}), 1.23$ 
$(3 \mathrm{H}, \mathrm{d}, J=6.4 \mathrm{~Hz}) ;{ }^{13} \mathrm{C}\left\{{ }^{1} \mathrm{H}\right\} \mathrm{NMR}\left(100 \mathrm{MHz}, \mathrm{CDCl}_{3}\right) \delta 162.0$, $159.9,157.9\left(\mathrm{~d}, J_{\mathrm{C}-\mathrm{F}}=249.9 \mathrm{~Hz}\right), 147.6,135.7,134.6,131.2\left(\mathrm{~d}, J_{\mathrm{C}-\mathrm{F}}\right.$ $=7.7 \mathrm{~Hz}), 130.7,127.2,127.0,126.6,125.0\left(\mathrm{~d}, J_{\mathrm{C}-\mathrm{F}}=3.8 \mathrm{~Hz}\right), 124.8$ $\left(\mathrm{d}, J_{\mathrm{C}-\mathrm{F}}=13.4 \mathrm{~Hz}\right), 120.4,117.1,116.9\left(\mathrm{~d}, J_{\mathrm{C}-\mathrm{F}}=20.0 \mathrm{~Hz}\right), 39.8$, 37.9, 19.1; MS $(m / z) 331\left(\mathrm{MNa}^{+}\right)$; HRMS calcd for $\mathrm{C}_{19} \mathrm{H}_{17} \mathrm{FN}_{2} \mathrm{NaO}-$ $\left(\mathrm{MNa}^{+}\right)$331.1223, found 331.1203. 2a': white solid; mp 86-88 ${ }^{\circ} \mathrm{C}$; IR (neat) $1694 \mathrm{~cm}^{-1}$; ${ }^{1} \mathrm{H}$ NMR $\left(400 \mathrm{MHz}, \mathrm{CDCl}_{3}\right) \delta 8.26(1 \mathrm{H}, \mathrm{dd}, J$ $=1.2,7.6 \mathrm{~Hz}), 7.72-7.80(2 \mathrm{H}, \mathrm{m}), 7.52(1 \mathrm{H}, \mathrm{m}), 7.46(1 \mathrm{H}, \mathrm{ddd}, J=$ $1.2,6.8,7.6 \mathrm{~Hz}), 7.27-7.35(3 \mathrm{H}, \mathrm{m}), 5.62(1 \mathrm{H}, \mathrm{m}), 4.97(1 \mathrm{H}, \mathrm{d}, J=$ $17.2 \mathrm{~Hz}), 4.94(1 \mathrm{H}, \mathrm{d}, J=10.0 \mathrm{~Hz}), 2.65(1 \mathrm{H}, \mathrm{td}, J=6.4,13.6 \mathrm{~Hz})$, $2.55(1 \mathrm{H}$, sext, $J=6.4 \mathrm{~Hz}), 2.34(1 \mathrm{H}, \mathrm{td}, J=6.8,13.6 \mathrm{~Hz}), 1.23(3 \mathrm{H}$, $\mathrm{d}, J=6.4 \mathrm{~Hz}) ;{ }^{13} \mathrm{C}\left\{{ }^{1} \mathrm{H}\right\}$ NMR $\left(100 \mathrm{MHz}, \mathrm{CDCl}_{3}\right) \delta 162.0,159.9$, $157.8\left(\mathrm{~d}, J_{\mathrm{C}-\mathrm{F}}=249.8 \mathrm{~Hz}\right), 147.6,135.6,134.6,131.3\left(\mathrm{~d}, J_{\mathrm{C}-\mathrm{F}}=7.7\right.$ $\mathrm{Hz}), 130.1,127.2,127.0,126.6,125.1\left(\mathrm{~d}, J_{\mathrm{C}-\mathrm{F}}=3.8 \mathrm{~Hz}\right), 124.9(\mathrm{~d}$, $\left.J_{\mathrm{C}-\mathrm{F}}=13.3 \mathrm{~Hz}\right), 120.4,116.9\left(\mathrm{~d}, J_{\mathrm{C}-\mathrm{F}}=20.0 \mathrm{~Hz}\right), 116.9,39.3,38.0$, 19.2; MS $(m / z) 331\left(\mathrm{MNa}^{+}\right)$; HRMS calcd for $\mathrm{C}_{19} \mathrm{H}_{17} \mathrm{FN}_{2} \mathrm{NaO}$ $\left(\mathrm{MNa}^{+}\right)$331.1223, found 331.1196.

$\left(P^{*}, S^{*}\right)$ - and $\left(P^{*}, R^{*}\right)$-3-(2-Fluorophenyl)-2-(4-methylpent-4ene-2-yl)quinazolin-4(3H)-one ( $2 b$ and $\left.2 b^{\prime}\right)$. $2 b$ and $2 b^{\prime}$ were prepared from $\mathrm{rac}-1 \mathrm{a}(80 \mathrm{mg}, 0.3 \mathrm{mmol})$ and methallyl bromide $(61$ $\mathrm{mg}, 0.45 \mathrm{mmol}$ ) in accordance with the procedure for synthesis of $\mathbf{2 a}$ and $2 a^{\prime}$. Purification of the residue by column chromatography (hexane/AcOEt $=4$ ) gave mixtures of $\mathbf{2} \mathbf{b}$ and $\mathbf{2} \mathbf{b}^{\prime}(84 \mathrm{mg}, \mathbf{8 6} \%)$. $\mathbf{2} \mathbf{b}$ and $\mathbf{2} \mathbf{b}^{\prime}$ were completely separated by MPLC (hexane/AcOEt $=7$ ) to give diastereomerically pure $\mathbf{2 b}$ and $\mathbf{2} \mathbf{b}^{\prime}$ (50 $\mathrm{mg}, 52 \% ; 24 \mathrm{mg}, 25 \%$ ). The diastereomeric ratio of $\mathbf{2} \mathbf{b}$ and $\mathbf{2} \mathbf{b}^{\prime}(2: 1)$ was determined on the basis of the isolated yield. $\mathbf{2 b}$ : white solid; $\mathrm{mp} 84-86{ }^{\circ} \mathrm{C}$; IR (neat) $1682 \mathrm{~cm}^{-1} ;{ }^{1} \mathrm{H}$ NMR $\left(400 \mathrm{MHz}, \mathrm{CDCl}_{3}\right) \delta 8.27(1 \mathrm{H}, \mathrm{dd}, J=1.2,8.4$ $\mathrm{Hz}), 7.72-7.80(2 \mathrm{H}, \mathrm{m}), 7.44-7.54(2 \mathrm{H}, \mathrm{m}), 7.27-7.36(3 \mathrm{H}, \mathrm{m})$, $4.69(1 \mathrm{H}, \mathrm{d}, J=1.6 \mathrm{~Hz}), 4.61(1 \mathrm{H}, \mathrm{d}, J=1.6 \mathrm{~Hz}), 2.71(1 \mathrm{H}, \mathrm{m}), 2.60$ $(1 \mathrm{H}, \mathrm{dd}, J=6.4,13.6 \mathrm{~Hz}), 2.15(1 \mathrm{H}, \mathrm{dd}, J=6.8,13.6 \mathrm{~Hz}), 1.42(3 \mathrm{H}$, s), $1.22(3 \mathrm{H}, \mathrm{d}, J=6.8 \mathrm{~Hz}) ;{ }^{13} \mathrm{C}\left\{{ }^{1} \mathrm{H}\right\} \operatorname{NMR}\left(100 \mathrm{MHz}, \mathrm{CDCl}_{3}\right) \delta$ $162.0,160.2,157.9\left(\mathrm{~d}, J_{\mathrm{C}-\mathrm{F}}=249.8 \mathrm{~Hz}\right), 147.6,142.6,134.6,131.2$ $\left(\mathrm{d}, J_{\mathrm{C}-\mathrm{F}}=7.6 \mathrm{~Hz}\right), 130.6,127.2,127.0,126.5,125.0\left(\mathrm{~d}, J_{\mathrm{C}-\mathrm{F}}=3.9\right.$ $\mathrm{Hz}), 124.8\left(\mathrm{~d}, J_{\mathrm{C}-\mathrm{F}}=13.3 \mathrm{~Hz}\right), 120.4,116.9\left(\mathrm{~d}, J_{\mathrm{C}-\mathrm{F}}=20.0 \mathrm{~Hz}\right)$, 112.9, 43.6, 36.1, 22.1, 18.6; MS $(\mathrm{m} / z) 345\left(\mathrm{MNa}^{+}\right)$; HRMS calcd for $\mathrm{C}_{20} \mathrm{H}_{19} \mathrm{FN}_{2} \mathrm{NaO}\left(\mathrm{MNa}^{+}\right) 345.1379$, found $345.1358 .2 \mathbf{b}^{\prime}$ : white solid; mp 92-94 ${ }^{\circ} \mathrm{C}$; IR (neat) $1682 \mathrm{~cm}^{-1} ;{ }^{1} \mathrm{H}$ NMR $\left(\mathrm{CDCl}_{3}\right) \delta 8.28(1 \mathrm{H}$, dd, $J=1.6,8.4 \mathrm{~Hz}), 7.71-7.80(2 \mathrm{H}, \mathrm{m}), 7.44-7.55(2 \mathrm{H}, \mathrm{m}), 7.28-$ $7.37(3 \mathrm{H}, \mathrm{m}), 4.70(1 \mathrm{H}, \mathrm{s}), 4.63(1 \mathrm{H}, \mathrm{s}), 2.70(1 \mathrm{H}, \mathrm{m}), 2.53(1 \mathrm{H}, \mathrm{dd}$, $J=5.6,14.0 \mathrm{~Hz}), 2.19(1 \mathrm{H}, \mathrm{dd}, J=8.8,14.0 \mathrm{~Hz}), 1.40(3 \mathrm{H}, \mathrm{s}), 1.21$ $(3 \mathrm{H}, \mathrm{d}, J=6.8 \mathrm{~Hz}) ;{ }^{13} \mathrm{C}\left\{{ }^{1} \mathrm{H}\right\} \mathrm{NMR}\left(\mathrm{CDCl}_{3}\right) \delta 162.0,160.2,157.9(\mathrm{~d}$, $\left.J_{\mathrm{C}-\mathrm{F}}=250.8 \mathrm{~Hz}\right), 147.6,142.4,134.6,131.3\left(\mathrm{~d}, J_{\mathrm{C}-\mathrm{F}}=7.6 \mathrm{~Hz}\right), 130.2$, $127.2,127.0,126.6,125.1\left(\mathrm{~d}, J_{\mathrm{C}-\mathrm{F}}=3.9 \mathrm{~Hz}\right), 124.9\left(\mathrm{~d}, J_{\mathrm{C}-\mathrm{F}}=13.3\right.$ $\mathrm{Hz}), 120.4,116.9\left(\mathrm{~d}, J_{\mathrm{C}-\mathrm{F}}=19.1 \mathrm{~Hz}\right), 113.0,43.3,35.9,21.6,18.5$; MS $(m / z) 345\left(\mathrm{MNa}^{+}\right)$; HRMS calcd for $\mathrm{C}_{20} \mathrm{H}_{19} \mathrm{FN}_{2} \mathrm{NaO}\left(\mathrm{MNa}^{+}\right)$ 345.1379 , found 345.1356 .

$\left(P^{*}, S^{*}\right)$ - and $\left(P^{*}, R^{*}\right)$-3-(2-Fluorophenyl)-2-(1-phenylpropan2-yl)quinazolin-4(3H)-one ( $2 c$ and $\left.2 c^{\prime}\right) .2 c$ and $2 c^{\prime}$ were prepared from rac-1a $(80 \mathrm{mg}, 0.3 \mathrm{mmol})$ and benzyl bromide $(77 \mathrm{mg}, 0.45$ $\mathrm{mmol}$ ) in accordance with the procedure for synthesis of $\mathbf{2 a}$ and $2 \mathrm{a}^{\prime}$. Purification of the residue by column chromatography (hexane/ AcOEt $=4)$ gave mixtures of $2 \mathrm{c}$ and $2 \mathrm{c}^{\prime}(88 \mathrm{mg}, 82 \%) .2 \mathrm{c}$ and $2 \mathrm{c}^{\prime}$ were completely separated by MPLC (hexane/AcOEt $=8$ ) to give diastereomerically pure $2 \mathrm{c}$ and $2 \mathbf{c}^{\prime}(50 \mathrm{mg}, 47 \% ; 32 \mathrm{mg}, 30 \%)$. The diastereomeric ratio of $2 \mathbf{c}$ and $2 \mathbf{c}^{\prime}$ (2:1) was determined on the basis of ${ }^{1} \mathrm{H}$ NMR analysis. 2c: colorless oil; IR (neat) $1684 \mathrm{~cm}^{-1}$; ${ }^{1} \mathrm{H}$ NMR $\left(400 \mathrm{MHz}, \mathrm{CDCl}_{3}\right) \delta 8.28(1 \mathrm{H}, \mathrm{d}, J=7.6 \mathrm{~Hz}), 7.80-7.84(2 \mathrm{H}, \mathrm{m})$, $7.44-7.52(2 \mathrm{H}, \mathrm{m}), 7.26(1 \mathrm{H}, \mathrm{t}, J=8.0 \mathrm{~Hz}), 7.15-7.21(3 \mathrm{H}, \mathrm{m})$, $7.15(1 \mathrm{H}, \mathrm{t}, J=8.0 \mathrm{~Hz}), 6.90-6.92(2 \mathrm{H}, \mathrm{m}), 6.36(1 \mathrm{H}, \mathrm{dt}, J=2.0,8.0$ $\mathrm{Hz}), 3.26(1 \mathrm{H}, \mathrm{dd}, J=8.0,12.4 \mathrm{~Hz}), 2.80(1 \mathrm{H}, \mathrm{m}), 2.74(1 \mathrm{H}, \mathrm{dd}, J=$ 5.2, $12.4 \mathrm{~Hz}), 1.33(3 \mathrm{H}, \mathrm{d}, J=6.4 \mathrm{~Hz}) ;{ }^{13} \mathrm{C}\left\{{ }^{1} \mathrm{H}\right\}$ NMR $(100 \mathrm{MHz}$, $\left.\mathrm{CDCl}_{3}\right) \delta 161.8,159.9,157.8\left(\mathrm{~d}, J_{\mathrm{C}-\mathrm{F}}=249.8 \mathrm{~Hz}\right), 147.6,139.7$, $134.6,131.0\left(\mathrm{~d}, J_{\mathrm{C}-\mathrm{F}}=7.7 \mathrm{~Hz}\right), 130.6,129.0,128.3,127.2,127.0$, $126.6,126.3,124.9\left(\mathrm{~d}, J_{\mathrm{C}-\mathrm{F}}=3.9 \mathrm{~Hz}\right), 124.6\left(\mathrm{~d}, J_{\mathrm{C}-\mathrm{F}}=13.4 \mathrm{~Hz}\right)$, $120.4,116.5\left(\mathrm{~d}, J_{\mathrm{C}-\mathrm{F}}=19.1 \mathrm{~Hz}\right), 42.3,40.6,19.7$; MS $(\mathrm{m} / z) 381$ $\left(\mathrm{MNa}^{+}\right)$; HRMS calcd for $\mathrm{C}_{23} \mathrm{H}_{19} \mathrm{FN}_{2} \mathrm{NaO}\left(\mathrm{MNa}^{+}\right) 381.1379$, found 381.1352. 2c' : white solid; mp $114-117^{\circ} \mathrm{C}$; IR (neat) $1688 \mathrm{~cm}^{-1} ;{ }^{1} \mathrm{H}$ NMR $\left(400 \mathrm{MHz}, \mathrm{CDCl}_{3}\right) \delta 8.30(1 \mathrm{H}, \mathrm{dd}, J=0.8,7.2 \mathrm{~Hz}), 7.78-7.83$ $(2 \mathrm{H}, \mathrm{m}), 7.55(1 \mathrm{H}, \mathrm{m}), 7.49(1 \mathrm{H}, \mathrm{m}), 7.29-7.37(3 \mathrm{H}, \mathrm{m}), 7.14-7.22$
(3H, m), 6.92-6.94 (2H, m), $3.20(1 \mathrm{H}, \mathrm{dd}, J=4.4,12.4 \mathrm{~Hz}), 2.78$ $(1 \mathrm{H}, \mathrm{m}), 2.74(1 \mathrm{H}, \mathrm{dd}, J=8.8,12.4 \mathrm{~Hz}), 1.22(3 \mathrm{H}, \mathrm{d}, J=6.4 \mathrm{~Hz})$; ${ }^{13} \mathrm{C}\left\{{ }^{1} \mathrm{H}\right\} \operatorname{NMR}\left(100 \mathrm{MHz}, \mathrm{CDCl}_{3}\right) \delta 161.9,159.9,157.9\left(\mathrm{~d}, J_{\mathrm{C}-\mathrm{F}}=\right.$ $250.7 \mathrm{~Hz}), 147.5,139.5,134.6,131.4\left(\mathrm{~d}, J_{\mathrm{C}-\mathrm{F}}=7.6 \mathrm{~Hz}\right), 130.2,129.0$, 128.2, 127.2, 127.0, 126.7, 126.2, $125.1\left(\mathrm{~d}, J_{\mathrm{C}-\mathrm{F}}=3.9 \mathrm{~Hz}\right), 124.8(\mathrm{~d}$, $\left.J_{\mathrm{C}-\mathrm{F}}=13.3 \mathrm{~Hz}\right), 120.5,116.9\left(\mathrm{~d}, J_{\mathrm{C}-\mathrm{F}}=19.1 \mathrm{~Hz}\right), 41.2,40.1,18.5$; MS $(m / z) 381\left(\mathrm{MNa}^{+}\right)$; HRMS calcd for $\mathrm{C}_{23} \mathrm{H}_{19} \mathrm{FN}_{2} \mathrm{NaO}\left(\mathrm{MNa}^{+}\right)$ 381.1379 , found 381.1353 .

$\left(P^{*}, S^{*}\right)$ - and $\left(P^{*}, R^{*}\right)$-3-(2-Fluorophenyl)-2-(3-methylbutan2-yl)quinazolin-4(3H)-one ( $2 \mathrm{~d}$ and $\left.2 \mathrm{~d}^{\prime}\right)$. Under $\mathrm{N}_{2}$ atmosphere, to the solution of rac-1a $(268 \mathrm{mg}, 1 \mathrm{mmol})$ in THF $(3.0 \mathrm{~mL})$ was added a THF solution of $\operatorname{LiN}\left(\mathrm{SiMe}_{3}\right)_{2}(1.3 \mathrm{M}, 1.15 \mathrm{~mL}, 1.5 \mathrm{mmol})$ at $\mathrm{rt}$, and the mixture was stirred for $30 \mathrm{~min}$ at $\mathrm{rt}$. Isopropyl iodide (255 $\mathrm{mg}, 1.5 \mathrm{mmol}$ ) was added to the mixture at $\mathrm{rt}$. After being stirred for $24 \mathrm{~h}$ at $\mathrm{rt}$, the mixture was poured into $\mathrm{NH}_{4} \mathrm{Cl}$ aq and extracted with AcOEt. The AcOEt extracts were washed with brine, dried over $\mathrm{MgSO}_{4}$, and evaporated to dryness. Purification of the residue by column chromatography (hexane/AcOEt $=6$ ) gave the mixtures of $\mathbf{2 d}$ and $\mathbf{2} \mathbf{d}^{\prime}$ (260 $\left.\mathrm{mg}, 84 \%\right)$. $\mathbf{2 d}$ and $\mathbf{2} \mathbf{d}^{\prime}$ were completely separated by MPLC (hexane/AcOEt $=8$ ) to give diastereomerically pure $\mathbf{2 d}$ and $\mathbf{2 d ^ { \prime }}$ (202 $\mathrm{mg}, 65 \%$ and $37 \mathrm{mg}, 12 \%$ ). The diastereomeric ratio of $\mathbf{2 d}$ and $2 \mathrm{~d}^{\prime}$ (5.4:1) was determined on the basis of the isolated yield. $2 \mathrm{~d}$ : white solid; mp $155-158{ }^{\circ} \mathrm{C}$; IR (neat) $1682 \mathrm{~cm}^{-1}$; ${ }^{1} \mathrm{H}$ NMR (400 $\left.\mathrm{MHz}_{\mathrm{CDCl}}\right) \delta 8.28(1 \mathrm{H}, \mathrm{d}, J=7.6 \mathrm{~Hz}), 7.71-7.76(2 \mathrm{H}, \mathrm{m}), 7.41-$ $7.51(2 \mathrm{H}, \mathrm{m}), 7.26-7.34(3 \mathrm{H}, \mathrm{m}), 2.12-2.25(2 \mathrm{H}, \mathrm{m}), 1.22(3 \mathrm{H}, \mathrm{d}, J$ $=6.0 \mathrm{~Hz}), 0.88(3 \mathrm{H}, \mathrm{d}, J=5.6 \mathrm{~Hz}), 0.81(3 \mathrm{H}, \mathrm{d}, J=6.0 \mathrm{~Hz}) ;{ }^{13} \mathrm{C}\left\{{ }^{1} \mathrm{H}\right\}$ $\operatorname{NMR}\left(100 \mathrm{MHz}, \mathrm{CDCl}_{3}\right) \delta 161.9,160.8,157.8\left(\mathrm{~d}, J_{\mathrm{C}-\mathrm{F}}=248.8 \mathrm{~Hz}\right)$, $147.6,134.4,131.1\left(\mathrm{~d}, J_{\mathrm{C}-\mathrm{F}}=8.6 \mathrm{~Hz}\right), 130.9,127.2,126.9,126.4$, $125.1\left(\mathrm{~d}, J_{\mathrm{C}-\mathrm{F}}=14.3 \mathrm{~Hz}\right), 125.0\left(\mathrm{~d}, J_{\mathrm{C}-\mathrm{F}}=3.9 \mathrm{~Hz}\right), 120.4,116.9(\mathrm{~d}$, $\left.J_{\mathrm{C}-\mathrm{F}}=19.0 \mathrm{~Hz}\right), 44.4,32.6,21.6,19.0,16.8 ; \mathrm{MS}(\mathrm{m} / z) 333\left(\mathrm{MNa}^{+}\right)$; HRMS calcd for $\mathrm{C}_{19} \mathrm{H}_{19} \mathrm{FN}_{2} \mathrm{NaO}\left(\mathrm{MNa}^{+}\right)$333.1379, found 333.1393. 2d': white solid; mp $145-150{ }^{\circ} \mathrm{C}$; IR (neat) $1686 \mathrm{~cm}^{-1}$; ${ }^{1} \mathrm{H}$ NMR $\left(400 \mathrm{MHz}, \mathrm{CDCl}_{3}\right) \delta 8.28(1 \mathrm{H}, \mathrm{dd}, J=0.8,8.0 \mathrm{~Hz}), 7.70-7.79(2 \mathrm{H}$, $\mathrm{m})$, 7.44-7.55 $(2 \mathrm{H}, \mathrm{m}), 7.24-7.34(3 \mathrm{H}, \mathrm{m}), 2.10-2.20(2 \mathrm{H}, \mathrm{m})$, $1.21(3 \mathrm{H}, \mathrm{d}, J=6.4 \mathrm{~Hz}), 0.87(3 \mathrm{H}, \mathrm{d}, J=6.4 \mathrm{~Hz}), 0.80(3 \mathrm{H}, \mathrm{d}, J=6.0$ $\mathrm{Hz}) ;{ }^{13} \mathrm{C}\left\{{ }^{1} \mathrm{H}\right\}$ NMR $\left(100 \mathrm{MHz}, \mathrm{CDCl}_{3}\right) \delta 162.0,160.9,157.8(\mathrm{~d}$, $\left.J_{\mathrm{C}-\mathrm{F}}=249.8 \mathrm{~Hz}\right), 147.7,134.6,131.3\left(\mathrm{~d}, J_{\mathrm{C}-\mathrm{F}}=7.6 \mathrm{~Hz}\right), 129.8,127.2$, $127.0,126.5,125.2\left(\mathrm{~d}, J_{\mathrm{C}-\mathrm{F}}=13.4 \mathrm{~Hz}\right), 125.1\left(\mathrm{~d}, J_{\mathrm{C}-\mathrm{F}}=3.8 \mathrm{~Hz}\right)$, $120.4,116.9\left(\mathrm{~d}, J_{\mathrm{C}-\mathrm{F}}=19.1 \mathrm{~Hz}\right), 45.0,31.9,21.5,19.3,17.4 ; \mathrm{MS}(\mathrm{m} /$ z) $333\left(\mathrm{MNa}^{+}\right)$; HRMS calcd for $\mathrm{C}_{19} \mathrm{H}_{19} \mathrm{FN}_{2} \mathrm{NaO}\left(\mathrm{MNa}^{+}\right)$333.1379, found 333.1373 .

$(P *, S *)-$ and $\left(P *, R^{*}\right)-3-(2-$ Fluorophenyl)-2-(1cyclohexylethyl)quinazolin-4(3H)-one (2e and $\left.2 e^{\prime}\right)$. 2e and $2 \mathbf{e}^{\prime}$ were prepared from rac-1a $(268 \mathrm{mg}, 1 \mathrm{mmol})$ and cyclohexyl iodide $(315 \mathrm{mg}, 1.5 \mathrm{mmol}$ ) in accordance with the procedure for synthesis of $\mathbf{2 d}$ and $\mathbf{2} \mathbf{d}^{\prime}$. Purification of the residue by column chromatography (hexane/AcOEt $=6$ ) gave mixtures of $2 \mathrm{e}$ and $2 \mathrm{e}^{\prime}$ (186 $\mathrm{mg}, 53 \%)$. 2e and $2 \mathrm{e}^{\prime}$ were completely separated by MPLC (hexane/AcOEt $=8)$ to give diastereomerically pure $2 \mathbf{e}$ and $2 \mathbf{e}^{\prime}(142$ $\mathrm{mg}, 41 \%$ and $29 \mathrm{mg}, 8 \%)$. The diastereomeric ratio of $2 \mathbf{e}$ and $2 \mathbf{e}^{\prime}$ (4.9:1) was determined on the basis of the isolated yield. 2e: white solid; mp $129-133{ }^{\circ} \mathrm{C}$; IR (neat) $1697 \mathrm{~cm}^{-1}$; ${ }^{1} \mathrm{H}$ NMR (400 MHz, $\left.\mathrm{CDCl}_{3}\right) \delta 8.27(1 \mathrm{H}, \mathrm{dd}, J=1.2,8.0 \mathrm{~Hz}), 7.72-7.79(2 \mathrm{H}, \mathrm{m}), 7.44-$ $7.54(2 \mathrm{H}, \mathrm{m}), 7.25-7.37(3 \mathrm{H}, \mathrm{m}), 2.22(1 \mathrm{H}$, quint, $J=6.8 \mathrm{~Hz})$, $1.80-1.89(2 \mathrm{H}, \mathrm{m}), 1.53-1.72(4 \mathrm{H}, \mathrm{m}), 1.03-1.28(3 \mathrm{H}, \mathrm{m}), 1.20$ $(3 \mathrm{H}, \mathrm{d}, J=6.8 \mathrm{~Hz}), 0.67-0.85(2 \mathrm{H}, \mathrm{m}) ;{ }^{13} \mathrm{C}\left\{{ }^{1} \mathrm{H}\right\} \mathrm{NMR}(100 \mathrm{MHz}$, $\left.\mathrm{CDCl}_{3}\right) \delta 162.1,161.1,157.9\left(\mathrm{~d}, J_{\mathrm{C}-\mathrm{F}}=249.8 \mathrm{~Hz}\right), 147.8,134.5$, $131.1\left(\mathrm{~d}, J_{\mathrm{C}-\mathrm{F}}=7.6 \mathrm{~Hz}\right), 131.0,127.2,127.0,126.4,125.1\left(\mathrm{~d}, J_{\mathrm{C}-\mathrm{F}}=\right.$ $13.4 \mathrm{~Hz}), 125.0\left(\mathrm{~d}, J_{\mathrm{C}-\mathrm{F}}=3.8 \mathrm{~Hz}\right), 120.3,116.9\left(\mathrm{~d}, J_{\mathrm{C}-\mathrm{F}}=20 \mathrm{~Hz}\right)$, 43.7, 42.4, 32.1, 29.6, 26.32, 26.30, 26.1, 16.8; MS $(\mathrm{m} / \mathrm{z}) 373$ $\left(\mathrm{MNa}^{+}\right)$; HRMS calcd for $\mathrm{C}_{22} \mathrm{H}_{23} \mathrm{FN}_{2} \mathrm{NaO}\left(\mathrm{MNa}^{+}\right) 373.1692$, found 373.1676. 2e': colorless oil; IR (neat) $1682 \mathrm{~cm}^{-1}$; ${ }^{1} \mathrm{H}$ NMR (400 $\left.\mathrm{MHz}^{\mathrm{CDCl}}\right)_{3} \delta 8.27(1 \mathrm{H}, \mathrm{dd}, J=0.8,8.4 \mathrm{~Hz}), 7.71-7.79(2 \mathrm{H}, \mathrm{m})$, 7.44-7.55 $(2 \mathrm{H}, \mathrm{m}), 7.22-7.34(3 \mathrm{H}, \mathrm{m}), 2.18(1 \mathrm{H}$, quint, $J=6.8 \mathrm{~Hz})$, $1.82-1.89(2 \mathrm{H}, \mathrm{m}), 1.52-1.71(4 \mathrm{H}, \mathrm{m}), 1.02-1.28(3 \mathrm{H}, \mathrm{m}), 1.20$ $(3 \mathrm{H}, \mathrm{d}, J=6.4 \mathrm{~Hz}), 0.70-0.80(2 \mathrm{H}, \mathrm{m}) ;{ }^{13} \mathrm{C}\left\{{ }^{1} \mathrm{H}\right\} \mathrm{NMR}(100 \mathrm{MHz}$, $\left.\mathrm{CDCl}_{3}\right) \delta 162.0,161.0,157.8\left(\mathrm{~d}, J_{\mathrm{C}-\mathrm{F}}=250.8 \mathrm{~Hz}\right), 147.7,134.6$, $131.3\left(\mathrm{~d}, J_{\mathrm{C}-\mathrm{F}}=8.5 \mathrm{~Hz}\right), 129.7,127.2,127.0,126.5,125.2\left(\mathrm{~d}, J_{\mathrm{C}-\mathrm{F}}=\right.$ $13.3 \mathrm{~Hz}), 125.1\left(\mathrm{~d}, J_{\mathrm{C}-\mathrm{F}}=3.8 \mathrm{~Hz}\right), 120.3,116.9\left(\mathrm{~d}, J_{\mathrm{C}-\mathrm{F}}=19.1 \mathrm{~Hz}\right)$, $43.9,41.4,31.7,29.5,26.31,26.27,26.2,17.0$; MS $(m / z) 373$ 
$\left(\mathrm{MNa}^{+}\right)$; HRMS Calcd for $\mathrm{C}_{22} \mathrm{H}_{23} \mathrm{FN}_{2} \mathrm{NaO}\left(\mathrm{MNa}^{+}\right)$373.1692, found 373.1667.

General Procedure for Synthesis of $3 a$ and $3 b$. Distilled triethylamine $(40 \mathrm{mmol})$ was added dropwise under nitrogen atmosphere to a solution of ortho-fluoroaniline $(20 \mathrm{mmol})$ in carbon disulfide $(38 \mathrm{~mL})$. The mixture was stirred at $\mathrm{rt}$ overnight. Then the precipitate was filtered, washed with $\mathrm{Et}_{2} \mathrm{O}$, and dried to give the dithiocarbamate salt as a light yellow solid. This salt was used without any further purification and immediately solubilized in acetonitrile (31 $\mathrm{mL})$. 2-Chlorocyclohexanone $(20 \mathrm{mmol})$ for $3 \mathrm{a}$ or 2 -chloroacetone $(20 \mathrm{mmol})$ for $\mathbf{3} \mathbf{b}$ was then added dropwise at $\mathbf{r t}$ under nitrogen atmosphere. The mixture was stirred $24 \mathrm{~h}$ at rt. Then a $37 \% \mathrm{HCl}$ solution $(5 \mathrm{~mL})$ was added dropwise, and the mixture was heated at reflux (oil bath) for $20 \mathrm{~min}$. The solvent was evaporated under reduced pressure, and water was added $(50 \mathrm{~mL})$. The mixture was extracted with dichloromethane $(3 \times 50 \mathrm{~mL})$; the organic layer was dried on $\mathrm{MgSO}_{4}$ and evaporated under reduced pressure. The desired product was purified by flash chromatography (petroleum etherdichloromethane, $60 / 40 \rightarrow 0 / 100)$.

3-(2-Fluorophenyl)-4,5,6,7-tetrahydro-1,3-benzothiazole-2(3H)thione (3a). Yield: $82 \%(4.4 \mathrm{~g})$; white solid; $\mathrm{mp} 162.4-164.8{ }^{\circ} \mathrm{C}$ (racemate); ${ }^{1} \mathrm{H}$ NMR $\left(400 \mathrm{MHz}, \mathrm{CDCl}_{3}\right) \delta 1.62-1.86(4 \mathrm{H}, \mathrm{m}, 2$ $\left.\mathrm{CH}_{2}\right), 2.11-2.12\left(2 \mathrm{H}, \mathrm{m}, \mathrm{CH}_{2}\right), 2.52-2.53\left(2 \mathrm{H}, \mathrm{m}, \mathrm{CH}_{2}\right), 7.28-7.33$ (3H, m, arom), 7.47-7.53 (1H, m, arom); ${ }^{13} \mathrm{C}\left\{{ }^{1} \mathrm{H}\right\}$ NMR $(100 \mathrm{MHz}$, $\left.\mathrm{CDCl}_{3}\right) \delta 21.6\left(\mathrm{CH}_{2}\right), 22.6\left(\mathrm{CH}_{2}\right), 23.1\left(\mathrm{CH}_{2}\right), 24.3\left(\mathrm{CH}_{2}\right), 117.0$ (d, CH, $J=19.1), 120.8(\mathrm{CH}), 124.9$ (d, C, $J=12.8), 125.0$ (d, CH, $J$ $=3.8$ ), $130.3(\mathrm{C}), 131.5$ (d, CH, $J=7.8), 137.1(\mathrm{C}), 157.2$ (d, C, $J=$ 253.0), 188.6 (C); HRMS (ESI/TOF) $\mathrm{m} / z[\mathrm{M}+\mathrm{H}]^{+}$calcd for $\mathrm{C}_{13} \mathrm{H}_{13} \mathrm{NS}_{2} \mathrm{~F}$ 266.0468, found 266.0471. Chiral HPLC: Whelk-O1 $(S, S), 25^{\circ} \mathrm{C}$, heptane/ethanol $60 / 40,1 \mathrm{~mL} / \mathrm{min}, \mathrm{UV}$ and polarimeter, $R_{\mathrm{t}_{1}}=6.72 \min (-), R_{\mathrm{t}_{2}}=8.26 \mathrm{~min}(+), k_{1}=1.24, k_{2}=1.75, \alpha=1.41$, and $R_{\mathrm{s}}=4.16$. First eluted (99\% ee): $[\alpha]_{\mathrm{D}}{ }^{25}-95.7$ (c 0.82, $\left.\mathrm{CHCl}_{3}\right)$.

3-(2-Fluorophenyl)-4-méthylthiazole-2(3H)-thione (3b). 3b was prepared in accordance with the procedure for the synthesis of $3 a$. Yield: $85 \%$ (3.8 g); white solid; $\mathrm{mp} 145-147{ }^{\circ} \mathrm{C}$ (racemate); ${ }^{1} \mathrm{H}$ NMR $\left(400 \mathrm{MHz}, \mathrm{CDCl}_{3}\right) \delta 1.95\left(3 \mathrm{H}, \mathrm{s}, \mathrm{CH}_{3}\right), 6.36(1 \mathrm{H}, \mathrm{s}, \mathrm{CH})$, 7.25-7.36 (3H, m, arom), 7.47-7.54 (1H, m, arom); ${ }^{13} \mathrm{C}\left\{{ }^{1} \mathrm{H}\right\} \mathrm{NMR}$ $\left(100 \mathrm{MHz}, \mathrm{CDCl}_{3}\right) \delta 15.4\left(\mathrm{CH}_{3}\right), 106.4(\mathrm{CH}), 117.1(\mathrm{~d}, \mathrm{CH}, J=$ 19.2 ), 125.2 (d, C, $J=13.2$ ), $125.3(\mathrm{~d}, \mathrm{CH}, J=3.8), 130.4(\mathrm{CH})$, 131.9 (d, CH, J = 7.7), 139.9 (C), 157.4 (d, C, $J=252.4$ ), 190.5 (C); HRMS (ESI/TOF) $\mathrm{m} / z[\mathrm{M}+\mathrm{H}]^{+}$calcd for $\mathrm{C}_{10} \mathrm{H}_{9} \mathrm{NS}_{2} \mathrm{~F} 226.0155$, found 226.0153. Chiral HPLC: Whelk-O1 $(S, S), 30^{\circ} \mathrm{C}$, hexane/2PrOH 80/20, $1 \mathrm{~mL} / \mathrm{min}, \mathrm{UV}, R_{\mathrm{t}_{1}}=12.5 \mathrm{~min}, R_{\mathrm{t}_{2}}=18.1, k_{1}=3.2, k_{2}=$ 5.0, $\alpha=1.58$, and $R_{\mathrm{s}}=6.96$. First eluted (99.5\% ee): $[\alpha]_{\mathrm{D}}{ }^{25}-107(c$ $\left.0.51, \mathrm{CHCl}_{3}\right)$.
(1) For reviews, see: (a) Alkorta, I.; Elguero, J.; Roussel, C.; Vanthuyne, N.; Piras, P. Atropisomerism and Axial Chirality in Heteroaromatic Compounds. Adv. Heterocycl. Chem. 2012, 105, 1. (b) Takahashi, I.; Suzuki, Y.; Kitagawa, O. Asymmetric Synthesis of Atropisomeric Compounds with an $\mathrm{N}-\mathrm{C}$ Chiral Axis. Org. Prep. Proced. Int. 2014, 46, 1. (c) Kumarasamy, E.; Raghunathan, R.; Sibi, M. P.; Sivaguru, J. Nonbiaryl and Heterobiaryl Atropisomers: Molecular Templates with Promise for Atropselective Chemical Transformations. Chem. Rev. 2015, 115, 11239.

(2) (a) Kishikawa, K.; Tsuru, I.; Kohmoto, S.; Yamamoto, M.; Yamada, K. Stereoselective Synthesis of 2-Alkylamino-N-(2'alkylphenyl)succinimide Conformers. Chem. Lett. 1994, 23, 1605. (b) Curran, D. P.; Qi, H.; Geib, S. J.; DeMello, N. C. Atroposelective Thermal Reactions of Axially Twisted Amides and Imides. J. Am. Chem. Soc. 1994, 116, 3131. (c) Kitagawa, O.; Izawa, H.; Sato, K.; Dobashi, A.; Taguchi, T.; Shiro, M. Optically Active Axially Chiral Anilide and Maleimide Derivatives as New Chiral Reagents: Synthesis and Application to Asymmetric Diels-Alder Reaction. J. Org. Chem. 1998, 63, 2634. (d) Hughes, A. D.; Price, D. A.; Simpkins, N. S. Atropisomeric Amides: Stereoselective Enolate Chemistry and Enantioselective Synthesis via a New $\mathrm{SmI}_{2}$-mediated Reduction. J. Chem. Soc., Perkin Trans. 1 1999, 1295. (e) Bach, T.; Schröder, J.; Harms, K. Diastereoselective Photocycloaddition of an Axial Chiral Enamide. Tetrahedron Lett. 1999, 40, 9003. (f) Dantale, S.; Reboul, V.; Metzner, P.; Philouze, C. First Use of Axially Chiral Thioamides for the Stereocontrol of C-C Bond Formation. Chem. - Eur. J. 2002, 8, 632. (g) Kitagawa, O.; Yoshikawa, M.; Tanabe, H.; Morita, T.; Takahashi, M.; Dobashi, Y.; Taguchi, T. Highly Enantioselective Synthesis of Atropisomeric Anilide Derivatives through Catalytic Asymmetric N-Arylation: Conformational Analysis and Application to Asymmetric Enolate Chemistry. J. Am. Chem. Soc. 2006, 128, 12923. (h) Clayden, J.; Turner, H.; Helliwell, M.; Moir, E. N,N'-Diarylureas: A New Family of Atropisomers Exhibiting Highly Diastereoselective Reactivity. J. Org. Chem. 2008, 73, 4415. (i) Nakazaki, A.; Miyagawa, K.; Miyata, N.; Nishikawa, T. Synthesis of a C-N Axially Chiral NArylisatin through Asymmetric Intramolecular N-Arylation. Eur. J. Org. Chem. 2015, 2015, 4603.

(3) (a) Oguz, S. F.; Dogan, I. Determination of Energy Barriers and Racemization Mechanisms for Thermally Interconvertable Barbituric and Thiobarbituric Acid Enantiomers. Tetrahedron: Asymmetry 2003, 14, 1857. (b) Yilmaz, E. M.; Dogan, I. Axially Chiral N-(o-aryl)-2thioxo-oxazolidine-4-one and Rhodanine Derivatives: Enantiomeric Separation and Determination of Racemization Barriers. Tetrahedron: Asymmetry 2008, 19, 2184. (c) Belot, V.; Farran, D.; Jean, M.; Albalat, M.; Vanthuyne, N.; Roussel, C. Steric Scale of Common Substituents from Rotational Barriers of $\mathrm{N}$-(o-Substituted aryl)thiazoline-2-thione Atropisomers. J. Org. Chem. 2017, 82, 10188.

(4) (a) Mannschreck, A.; Koller, H.; Stühler, G.; Davis, M. A.; Traber, J. The Enantiomers of Methaqualone and Their Unequal Anticonvulsive Activity. Eur. J. Med. Chem. Chim. Ther. 1984, 19, 381. (b) Junghänel, J.; Buss, V.; Beyrich, T.; Jira, T. Circular Dichroism of Axially Chiral Methaqualone, 3-Aryl-2-mercapto- and 3-aryl-2alkylthio-4(3H)-quinazolinones: Conformational Dependence of CD and Assignment of Absolute Configuration. Chirality 1998, 10, 253. (c) Welch, W. M.; Ewing, F. E.; Huang, J.; Menniti, F. S.; Pagnozzi, M. J.; Kelly, K.; Seymour, P. A.; Guanowsky, V.; Chenard, B. L.; Guhan, S.; Guinn, M. R.; Critchett, D.; Lazzaro, J.; Ganong, A. H.; DeVries, K. M.; Staigers, T. L.; Chenard, B. L. Atropisomeric Quinazolin-4-one Derivatives Are Potent Noncompetitive $\alpha$-amino-3hydroxy-5-methyl-4-isoxazolepropionic acid (AMPA) receptor Antagonists. Bioorg. Med. Chem. Lett. 2001, 11, 177. (d) Chenard, B. L.; Welch, W. M.; Blake, J. F.; Butler, T. W.; Reinhold, A.; Ewing, F. E.; Menniti, F. S.; Pagnozzi, M. J. Quinazolin-4-one $\alpha$-Amino-3-hydroxy- 
5-methyl-4-isoxazolepropionic Acid (AMPA) Receptor Antagonists: Structure-Activity Relationship of the C-2 Side Chain Tether. J. Med. Chem. 2001, 44, 1710. (e) Dolma, S.; Lessnick, S. L.; Hahn, W. C.; Stockwell, B. R. Identification of Genotype-selective Antitumor Agents Using Synthetic Lethal Chemical Screening in Engineered Human Tumor Cells. Cancer Cell 2003, 3, 285. (f) Tokitoh, T.; Kobayashi, T.; Nakada, E.; Inoue, T.; Yokoshima, S.; Takahashi, H.; Natsugari, H. Diastereoselective Synthesis of Atropisomeric 3-(2Substituted Aryl)quinazolin-4-ones and Their Stereochemical Properties. Heterocycles 2006, 70, 93. (g) Hirai, M.; Terada, S.; Yoshida, H.; Ebine, K.; Hirata, T.; Kitagawa, O. Catalytic Enantioselective Synthesis of $\mathrm{N}-\mathrm{C}$ Axially Chiral Mebroqualone and Its Derivatives through Reductive Asymmetric Desymmetrization. Org. Lett. 2016, 18,5700 .

(5) (a) Jira, T.; Schopplich, C.; Bunke, A.; Leuthold, L.; Junghänel, J.; Theiss, R.; Kottke, K.; Besch, A.; Beyrich, T. Synthesis and HPLCseparation of Atropisomeric and Central Chiral 3-aryl-2-mercaptoand 3-aryl-2-alkylthio-4(3H)-quinazolinone Derivatives on Chiral Stationary Phases-Part 2: Chiral Enantiomeric Separation. Pharmazie 1996, 51, 379. (b) Hoffmann, U.; Bscharat, N.; Jira, T. Effects of quinazolin- $(3 \mathrm{H}, 1 \mathrm{H})$-4-one-2-thiones with Axial and Central Chirality on The Contractile Response of Smooth Muscle. Pharmazie 1996, 51, 664.

(6) Schroder, C. E.; Yao, T.; Sotsky, J.; Smith, R. A.; Roy, S.; Chu, Y.-K.; Guo, H.; Tower, N. A.; Noah, J. W.; McKellip, S.; Sosa, M.; Rasmussen, L.; Smith, L. H.; White, E. L.; Aubé, J.; Jonsson, C. B.; Chung, D.; Golden, J. E. Development of (E)-2-((1,4-Dimethylpiperazin-2-ylidene)amino)-5-nitro- $N$-phenylbenzamide, ML336: Novel 2Amidinophenylbenzamides as Potent Inhibitors of Venezuelan Equine Encephalitis Virus. J. Med. Chem. 2014, 57, 8608.

(7) Hasegawa, F.; Kawamura, K.; Tsuchikawa, H.; Murata, M. Stable $\mathrm{C}-\mathrm{N}$ axial chirality in 1-Aryluracil Scaffold and Differences in in vitro Metabolic Clearance between Atropisomers of PDE4 inhibitor. Bioorg. Med. Chem. 2017, 25, 4506.

(8) Mintas, M.; Mihaljevic; Koller, H.; Schuster, D.; Mannschreck, A. Sterically Hindered $\mathrm{N}$-aryl-2(1H)-quinolones and $\mathrm{N}$-aryl-6(5H)phenanthridinones: Separation of Enantiomers and Barriers to Racemization. J. Chem. Soc., Perkin Trans. 2 1990, 619.

(9) (a) Matsuoka, M.; Goto, M.; Wzorek, A.; Soloshonok, V.; Kitagawa, O. Diastereoselective $\alpha$-Alkylation of Metallo Enamines Generated from N-C Axially Chiral Mebroqualone Derivatives. Org. Lett. 2017, 19, 2650. (b) Matsuoka, M.; Iida, A.; Kitagawa, O. $\alpha$ Alkylation of N-C Axially Chiral Quinazolinone Derivatives Bearing Various ortho-Substituted Phenyl Groups: Relation between Diastereoselectivity and the ortho-Substituent. Synlett 2018, 29, 2126.

(10) Miller et al. evaluated that the rotational barrier of 2-methyl-3(2-fluorophenyl)quinazolinon-4-one is ca. $26 \mathrm{kcal} / \mathrm{mol}$ by DFT calculation, while the experimental value has not been described: (a) Diener, M. E.; Metrano, A. J.; Kusano, S.; Miller, S. J. Enantioselective Synthesis of 3-Arylquinazolin-4(3H)-ones via Peptide-Catalyzed Atroposelective Bromination. J. Am. Chem. Soc. 2015, $137,12369$.

(11) (a) Roussel, C.; Adjimi, M.; Chemlal, A.; Djafri, A. Comparison of Racemization Processes in 1-arylpyrimidine-2-thione and 3arylthiazoline-2-thione Atropisomers and Their Oxygen Analogs. J. Org. Chem. 1988, 53, 5076. (b) Vanthuyne, N.; Andreoli, F.; Fernandez, S.; Roman, M.; Roussel, C. Synthesis, Chiral Separation, Barrier to Rotation and Absolute Configuration of $\mathrm{N}-(\mathrm{O}$ - Functionalized-aryl)-4-alkyl-thiazolin-2-one and Thiazoline-2-thione Atropisomers. Lett. Org. Chem. 2005, 2, 433. (c) Mehdid, M. A.; Djafri, A.; Andreoli, F.; Vanthuyne, N.; Farran, D.; Niebler, J.; Buettner, A.; Giorgi, M.; Roussel, C. Metathetic Sulfur Transfer Mediated by N-(2aminophenyl)-4-methyl-thiazolin-2-thione Derivatives. Part III: An alkylthiol- and thioacid-free Route to Diversely Substituted $S$-alkyl Thioesters. Tetrahedron 2013, 69, 4994.

(12) Colebrook, L. D.; Giles, H. D.; Granata, A.; Icli, S.; Fehlner, J. R. Restricted Internal Rotation in 1-Arylhydantoins, 3-Arylhydantoins and 3-Aryl-2-Thiohydantoins: Reversal of the Effective Sizes of Methyl and Chlorine. Can. J. Chem. 1973, 51, 3635.
(13) Belot, V. Accès à une bibliothèque ciblée de $N$-aryl-thiazoline2-thiones pour l'établissement d'une nouvelle échelle de taille de substituants usuels. Thesis Aix-Marseille University, 2017. http:// www.theses.fr/2017AIXM0408.

(14) Although stereocontrol based on a chiral carbon and involving a fluorine atom has been reported, in most cases, the diastereoselectively is due to chelation control between a carbonyl oxygen and a fluorine atom or the $\pi^{*}-\sigma^{*}{ }_{\mathrm{C}-\mathrm{F}}$ conjugation. Representative papers: (a) Kitazume, T.; Kobayashi, T.; Yamamoto, T.; Yamazaki, T. A Highly Stereocontrolled Synthetic Approach to Versatile Monofluorinated Molecules. J. Org. Chem. 1987, 52, 3218. (b) Fujita, M.; Ishizuka, H.; Ogura, K. Electronic Effects on $\pi$-facial Stereoselectivity in Electrophilic Additions to Allylic Bonds: Stereoselective Epoxidation of Allylic Fluorides. Tetrahedron Lett. 1991, 32, 6355. (c) Myers, A. G.; Barbay, J. K.; Zhong, B. Asymmetric Synthesis of Chiral Organofluorine Compounds: Use of Nonracemic Fluoroiodoacetic Acid as a Practical Electrophile and Its Application to the Synthesis of Monofluoro Hydroxyethylene Dipeptide Isosteres within a Novel Series of HIV Protease Inhibitors. J. Am. Chem. Soc. 2001, 123, 7207. (d) Billings, S. B.; Woerpel, K. A. Nucleophilic Substitution Reactions of Sulfur-Substituted Cyclohexanone Acetals: An Analysis of the Factors Controlling Stereoselectivity. J. Org. Chem. 2006, 71, 5171. (e) Mohanta, P. K.; Davis, T. A.; Gooch, J. R.; Flowers, R. A., II Chelation-Controlled Diastereoselective Reduction of $\alpha$-Fluoroketones. J. Am. Chem. Soc. 2005, 127, 11896. On the other hand, to the best of our knowledge, the stereocontrol based on simple steric discrimination between hydrogen and fluorine atoms has so far been uncommon.

(15) When diastereomerically pure $\mathbf{2 a}, \mathbf{2 c}$, and $2 \mathrm{e}$ were heated for 8 $\mathrm{h}$ at $80^{\circ} \mathrm{C}$ in toluene, equilibrium mixtures of the diastereomers $(\mathbf{2 a}$ / $2 \mathbf{a}^{\prime}=1, \mathbf{2 c} / \mathbf{2} \mathbf{c}^{\prime}=1.8$, and $\left.\mathbf{2 e} / \mathbf{2 \mathbf { e } ^ { \prime }}=3.5\right)$ were obtained.

(16) Smart, B. E. Fluorine substituent effects (on bioactivity). J. Fluorine Chem. 2001, 109, 3.

(17) CCDC 1868507 (2d) contains the supplementary crystallographic data for this paper. These data can be obtained free of charge from The Cambridge Crystallographic Data Centre via www.ccdc. com.ac.uk/data request/cif.

(18) (a) Peluso, P.; Mamane, V.; Aubert, E.; Cossu, S. Recent Trends and Applications in Liquid-phase Chromatography Enantioseparation of Atropisomers. Electrophoresis 2017, 38, 1830. (b) LaPlante, S. R.; Fader, L. D.; Fandrick, K. R.; Fandrick, D. R.; Hucke, O.; Kemper, R.; Miller, S. P. F.; Edwards, P. J. Assessing Atropisomer Axial Chirality in Drug Discovery and Development. J. Med. Chem. 2011, 54, 7005 .

(19) Meanwell, N. A. Fluorine and Fluorinated Motifs in the Design and Application of Bioisosteres for Drug Design. J. Med. Chem. 2018, $61,5822$. 